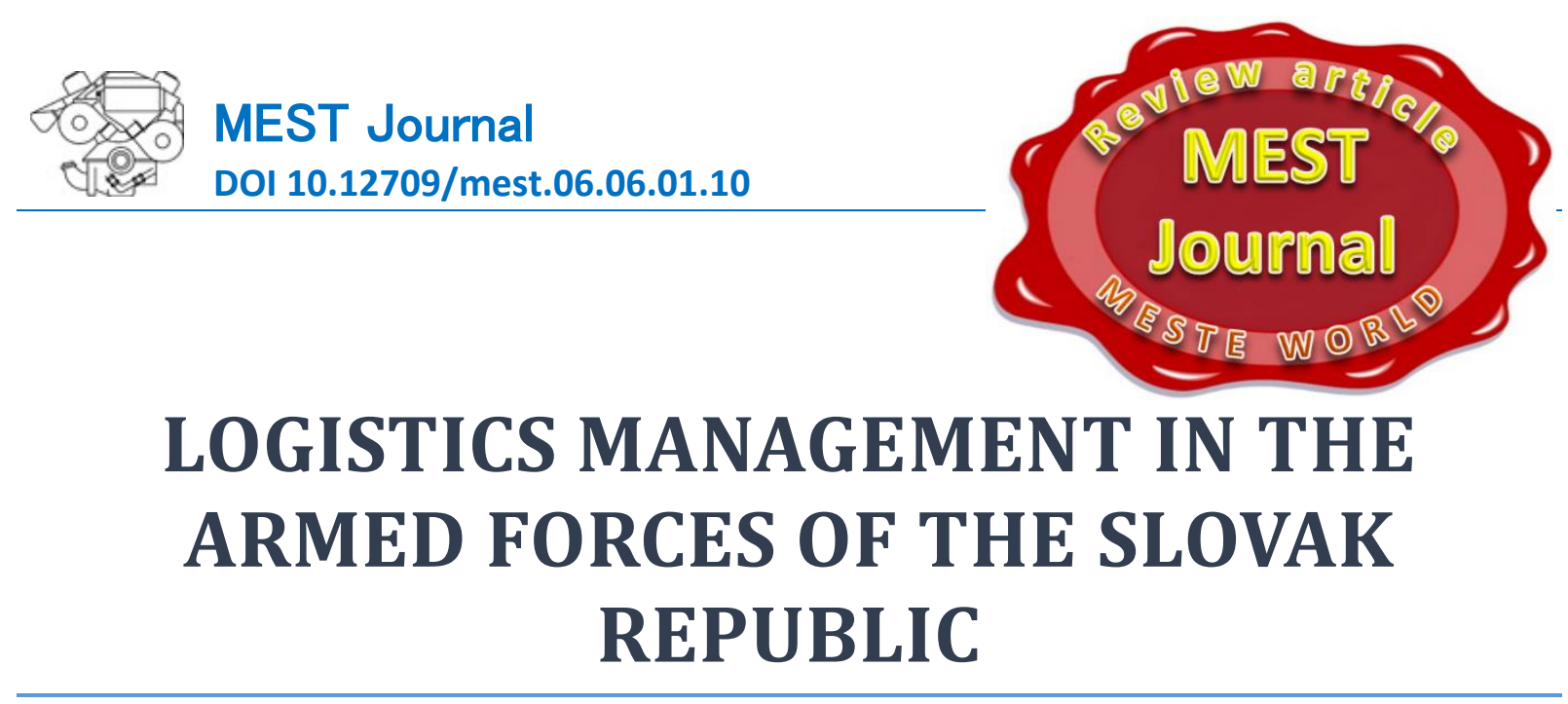

\title{
Miroslav Skolnik
}

\author{
Management Department, Armed Forces Academy of General M. R. Stefanik \\ in Liptovsky Mikulas, Slovak Republic
}

OMESTE

JEL Category: H56

\begin{abstract}
Logistics in the Armed Forces of the Slovak Republic (AF SR) now gains importance and is irreplaceable in the comprehensive security of the complex combat activities of troops. Logistics management is implemented in activities such as planning, organization, implementation, control, and assistance in all logistics functional areas. Modern logistics management in the Slovak armed forces must be flexibly adapted to the individual levels of command and control of troops. Managing the flow of material flow in the Slovak Republic according to the proven principle: "just in time" requires adequate structures at individual levels of management, closely linked to the information, communication and recording system. The Military Doctrine of the Slovak Republic establishes three levels of war - strategic, operational and tactical, which are applied in war and non-military operations. However, in today's international environment, it is not possible to determine with certainty at what level the organizational structure operates. All levels are interconnected. The Ministry of Defence and the General Staff of the Slovak Armed Forces focus on the strategic logistics management. The logistics office resolves operational and some strategic logistics issues. Logistics departments of ground and air forces deal with operational logistics management, influencing the tasks imposed on the commander in the operational plan for the use of Slovak armed forces, including the creation of procedures, doctrines and training documents. At a tactical level, the logistics of departments and units are organically integrated into the structures of their headquarters with their subordinate logistics units. The paper deals with the structure of logistics management in the AF SR and the role of its individual elements at the strategic, operational and tactical level. Finally, it shows possible ways and goals of logistics management for the future.
\end{abstract}

Keywords: Logistics Management, Armed Forces of the Slovak Republic, Strategic, Operational and Tactical Logistics.

Address of the author:

Miroslav Školník

誊=" miroslav.skolnik@aos.sk

\section{INTRODUCTION}

Due to the limited amount of funds available and the need to respond to the changed source framework, it is assumed that the construction of the Slovak Armed Forces logistics will continue 
according to the set priorities of importance in the following content.

The construction of units and equipment for logistic support of high-preparedness units is one of the most important tasks in the construction of logistics support of the Slovak Republic in the fulfillment of the commitments declared to NATO, in particular, the construction of units allocated to high-preparedness. In order to ensure the continuous logistic support of Slovak Armed Forces units operating outside the Slovak Republic, their logistic support units must be built first.

Construction and filling of inventories for units deployed in high-level forces are a further challenge for units of high alert forces, which must be preferentially equipped with specified supplies, to cover the needs for 30 days.

Equipping high-security troops with NATO-armed forces, equipment and materials compatible with NATO forces where the aim is primarily to provide strategic means of transport, material handling, compatibility in the basic areas, in particular, the single fuel on the battlefield, the transport of fuel and the possibility of confusion of ammunition on the battlefield. Once these basic objectives are met, further steps will be taken leading to greater compatibility.

Organizational and material security of the tasks of the Slovak Armed Forces are resulting from the obligation to provide security by the host country presupposes in this area the initiation of the preparation of the territory of the Slovak Republic and the assigned forces to fulfil the tasks arising from the Slovak Republic's commitment to the host country towards NATO.

The gradual replenishment of inventory for lowerlevel units will be timed according to the real availability of funds and other necessary resources.

Removing surplus and unnecessary material will allow a more efficient use of limited available resources.

The gradual modernization of logistic elements for logistic support on the territory of the Slovak Republic clearly declares the needs for the logistic support infrastructure in the Slovak Republic, which will allow efficient replenishment from sources outside the defense sector. The fulfillment of these tasks will be technologically tied to the acquisition of a new or modernization of the existing technique. This will be based on the perspective of the crew.

The gradual replacement and modernization of equipment, technology, and materials will allow increasing the required capabilities of the Slovak Republic as a whole in the long run.

The logistics system must be prompt, capable of anticipating logistical requirements in a timely manner, maintain inventory flow and concentrate limited logistics resources where necessary, depending on the operational tempo and combat requirements. Organization of logistics must be based on real possibilities, to be modular and capable of rapid reaction. Distributed logistics is a new way of support whereby the amount is replaced by the speed and the flow of material through its stream. The key is the material in motion, with the stock becoming a distribution network. In such a supply network, the amount of stored stock is reduced and replaced by rapid transmission of material in the distribution network.

In the sphere of logistics, the development of the Slovak Armed Forces will focus on functional areas with an emphasis on the acquisition of the required competencies in the following areas:

- the strategic, operational and tactical mobility of logistics: to rapidly adapt to the requirements of strategic aviation, maritime and rail strategic transport, and to have the necessary transport and handling equipment, military and strategic transportation material, and to master standard operational procedures in the field of strategic transport and munitions.

- the resilience of logistics: Introduce material to the Slovak Armed Forces in order to ensure the fulfillment of the logistic support tasks in difficult climatic conditions (catering, material reserves, etc.) and to have trained and appropriately armed personnel.

- multinational integrated logistics: to contribute value to the planned integrated logistics structures of the Allies.

- countries in the role of specialist: to improve the supply and repair system and to modernize the technique. Services to customize or purchase.

- ensuring the sustainability of national forces and contributing to the sustainability of the coalition 
forces: deploying sufficiently large national support elements (NSEs) with sufficient reserve capacities and supplies.

- providing logistical support in the contract placement area: on the basis of a logistic survey, provide ready staff with efficient logistical support and services in the contract placement area.

- building and maintaining stationery and field infrastructure: Building and modernizing accommodation, catering and other facilities, thereby contributing to improving the lives of professional troops

- use of intelligence: Use them effectively in planning and implementing logistical support

Learning and use in the logistics support planning method based on effects (EBO - Effect Based Operations, EBA - Effect Base Approach): A new approach to planning an operation. It is conditional on a new type of operations against structured systems (CAS Comprehensive Adaptive System, against terrorist organizations), which differ significantly from classical military structures.

\section{MANAGEMENT OF LOGISTICS IN INDIVIDUAL STATISTICS ARMED FORCES OF THE SR}

The Military Doctrine establishes three levels of war - strategic, operational, and tactical, applied in both war and non-military operations. However, in today's international environment, it is not possible to determine with certainty at what level the organizational structure operates. All levels are interconnected. The battalion commander may, for example, be the commander of a national contingent in the field of war operations that deals with tactical activities. However, it can also perform tasks (such as interaction with other types of forces or host states) that are usually associated with the operating level. To perform these functions, organizational structures must be strengthened in many cases. Military activities at one level can simultaneously meet higher-level goals. Logistics activity takes place at all levels. There is no definitive line of differentiation at each level. The difference lies in the sense and not in the type of activity. For example, the development of logistics equipment may be an activity at any level (Trebula, 2016). The development of a brigade space of support by a logistic support battalion to maintain troops in combat represents the function of logistic support at the tactical level. The development of a base to support a joint operational group in the implementation of a complex operation is a function at the operational level, but the establishment of a base in the area of war operations outside the Slovak Republic is an activity at the strategic level. The establishment of a permanent logistics base in the territory of the state is a strategic task at the national level to support a military strategy not only of one operation or mission within the combat area. The Ministry of Defence of the Slovak Republic and the General Staff of the Armed Forces of the Slovak Republic concentrate on the problems of strategic logistics. The Headquarters of Training and Support forces resolve operational issues, and some issues of strategic logistics and ground and air force logistics departments address operational logistics issues affecting the performance of the tasks outlined in the Plan of Use of the Armed Forces of the SR, including the creation of procedures, doctrine, and training. In responsibility, subordinate commanders and unitlevel logistics officers deal with tactical tasks (Skolnik \& Belan, 2015). However, the resolution is not always clear. The logistical support system for the armed forces is one-sided and one level overlaps with the other. This is particularly true in non-military operations, in which support personnel does not provide support to armed forces in combat in a traditional sense. The Ministry of Defence and the General Staff of the Slovak Armed Forces focus on the issue of strategic logistics.

After reorganization logistics, the many competencies will be transferred to the newly established Logistics Office directly subordinated to the GS Slovak Armed Forces and to the components of ground and air force logistics.

The Ground and Air Forces Logistics Departments address the issues of operational logistics affecting the role of commanders in the operational plan for the use of the Slovak armed forces, including the creation of procedures, doctrine, and training. In responsibility, subordinate commanders and unit-level logistics officers deal with tactical tasks. All levels are interconnected. The current basic structure of Slovak Armed Forces logistics is shown in Fig. 1. 


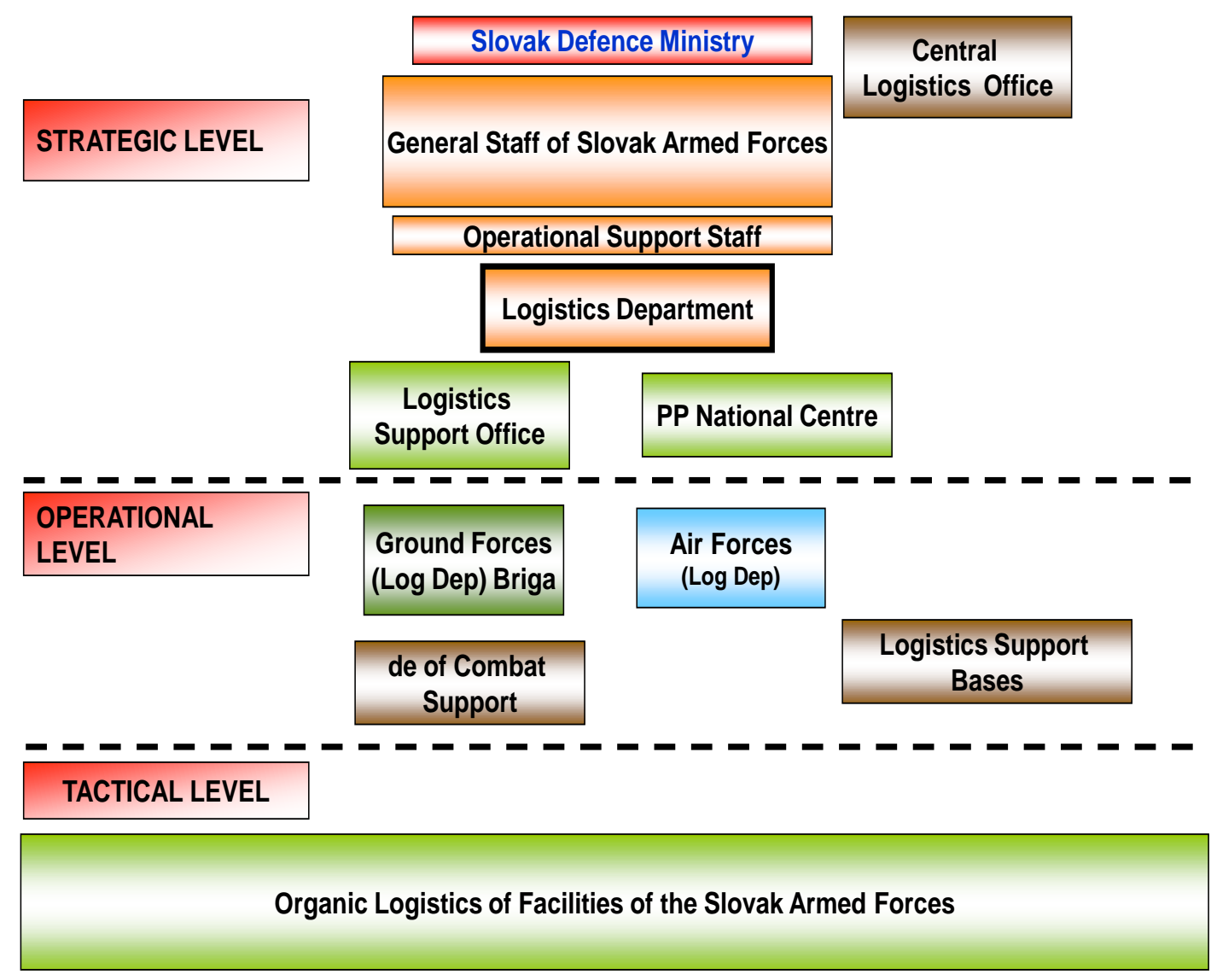

Fig. 1 Organizational structure of logistics of the Slovak armed forces

(Source: Logistics Department - Operational Support Staff of the SAF)

\section{STRATEGIC LEVEL OF LOGISTICS MANAGEMENT}

At the national strategic level, logistical support to a large extent is within the competence of the industrial and civil sectors. Armed forces include political and military-strategic leadership as well as civilian and military contractors. At this level, logistics combines the state's economic base (human and material resources, industry) with military operations in the area of war, enabling the state, and especially its armed forces, to achieve its goals.

The ability of the defense industry to produce and supply military material has a decisive impact on the conduct of armed conflict (Marchevka, 2015). Logistics authorities at the strategic level are the linkages between the industrial base and logistics at the operational level.

At the strategic level, the Ministry of Defence of the Slovak Republic, the General Staff of the Armed Forces of the Slovak Republic, other central government bodies (in particular the Ministry of Economy, the Ministry of Transport, Post and Telecommunications, the Ministry of Construction and Regional Development, the Ministry of Agriculture, the Ministry of Health, material reserves) and civilian suppliers.

Logistics authorities at the strategic level are focused on:

- establishing the necessary resources,

- acquisition of resources,

- integration of information systems for the management of resources of all elements of the armed forces and state administration bodies,

- maintaining national healthcare systems and facilities,

- identification of mobilization requirements and mobilization stocks;

- maintaining the productive capabilities of military material in peace and industrial growth, 
- base in time of war,

- ensuring strategic moves,

- concentrating forces and logistics resources before starting the operation,

- the re-establishment of the military capabilities of the state,

- demobilization of the armed forces.

The strategic level of logistics consists of the following bodies, agencies and facilities of the Slovak Ministry of Defence:

- Management Section of Slovak Defence Ministry,

- Central Logistics Office,

- Modernization and Infrastructure Section of Slovak Defence Ministry,

- Logistics of the Operations Support Staff of the General Staff of the Slovak Republic (J-4),

- Budget Chapter Administration Office,

- Investments and Acquisitions Office,

The strategic level of logistics is shown in figures 2 and 3.

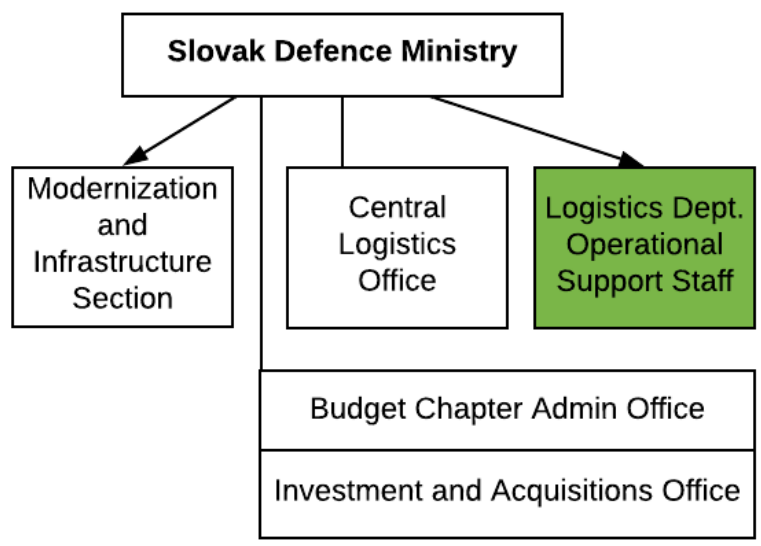

Fig. 2 Strategic level of Slovak Armed Forces logistics (model)
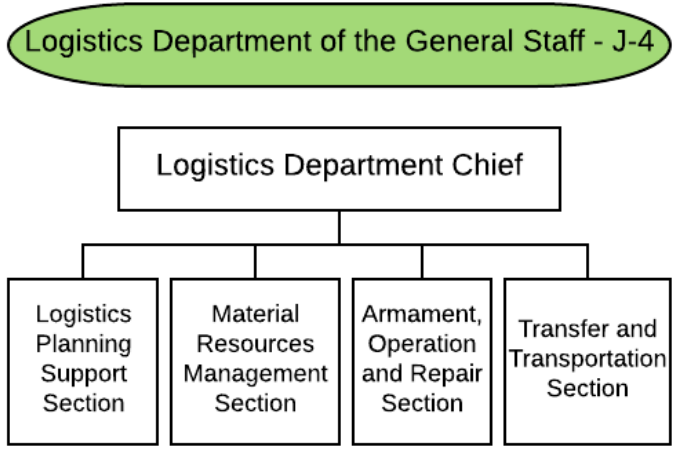

Fig. 3 Department of logistics of General Staff of the Slovak Armed Forces -J-4 (model)

\section{OPERATIONAL LEVEL OF LOGISTICS MANAGEMENT}

At the operational level, the tasks of consumer logistics are planned, coordinated and fulfilled. The following bodies, units and logistics units of the Slovak Armed Forces:

a) Logistics Department of the Ground Force Command of the Slovak Armed Forces,

b) Logistics Department of the Air Force Command of the Slovak Armed Forces,

c) The Office of Logistics.

The operational level of logistics in the Ground Force Command of the Slovak Armed Forces is shown in Figure 4.
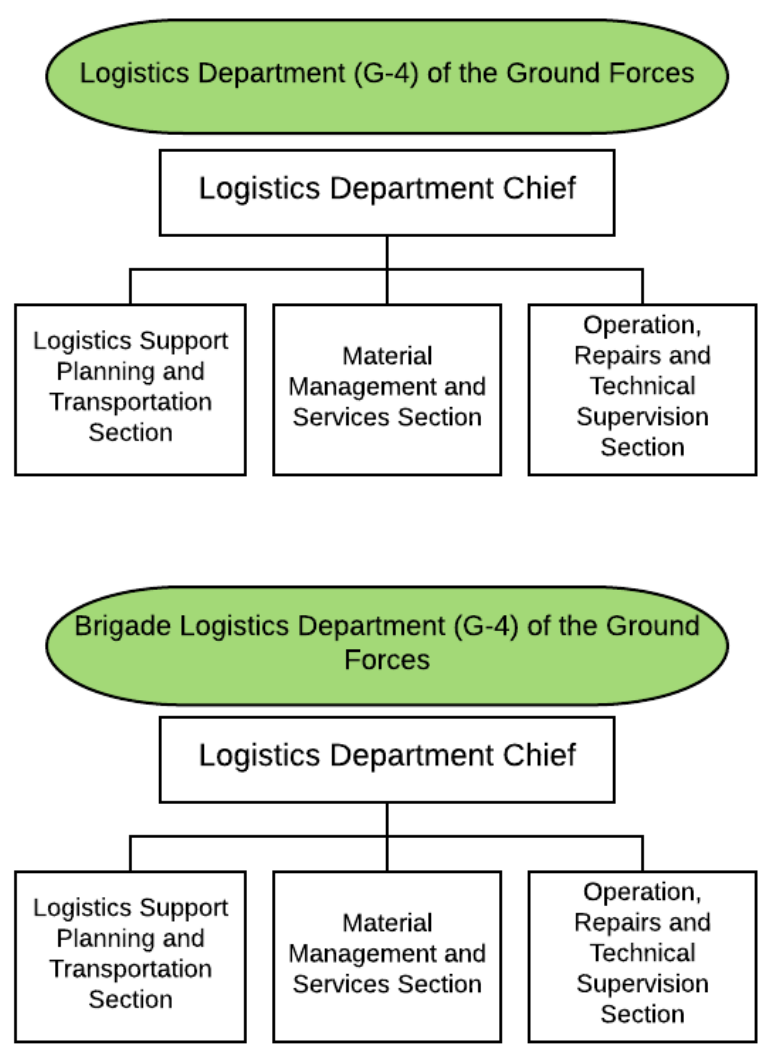

Fig. 4 Operational Level of Logistics in Ground Force Command of Slovak Armed Forces, (model).

The operational level of logistics in the Air Force Command of Slovak Armed Forces is shown in Figure 5. 
Logistics Department (G-4) of the Air Forces
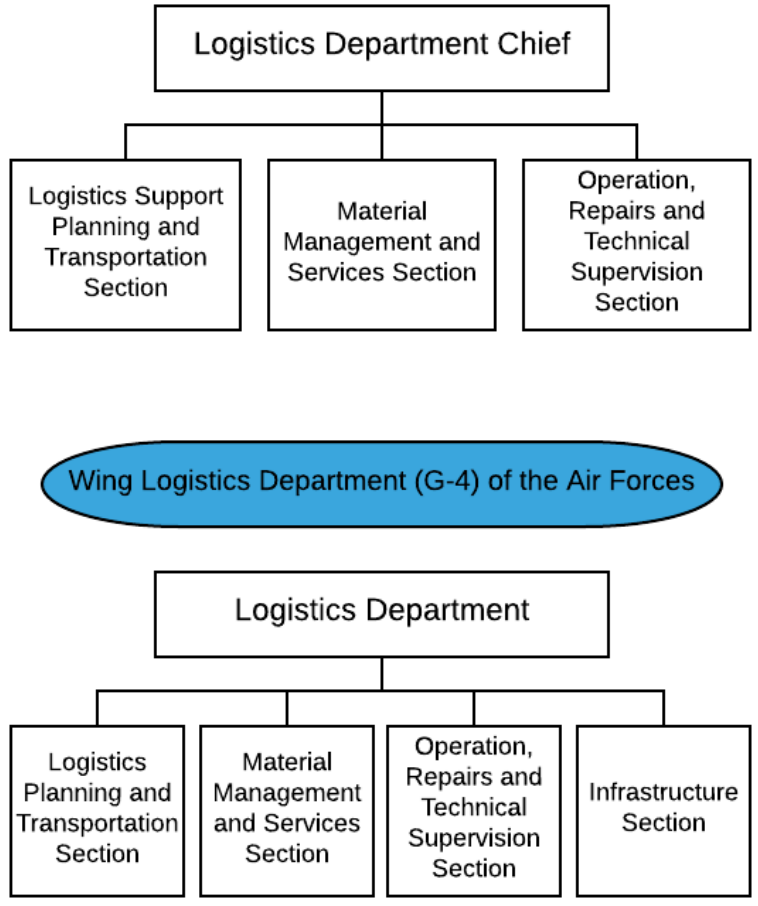

Fig. 5 Operational level of logistics in the Air Force Command of the Slovak Armed Forces (model)

Common principles of logistical support at the operational level will be detailed in the forthcoming Operational Logistics Doctrine of the Armed Forces of the Slovak Republic.

\section{TACTICAL LEVEL OF LOGISTICS MANAGEMENT}

The tactical level is the lowest, efficient level of logistics. At the tactical level, the tasks of consumer logistics are planned, coordinated and fulfilled. To support the fulfillment of these tasks, the logistics authorities at the tactical level of the Slovak Armed Forces, shown in figure 6, are designated.

Organic elements of ground forces are units and logistics units. They perform tasks in the field of transport, technical security, tire services and allround material security (Brezula, 2017). The organizational structure of the Ground Forces Brigades incorporates logistics support battles. Separate battalions have battle organizations in organizational structures.

Similarly, the organic component of the air force is the logistics unit. It fulfills tasks in the field of engineering - airport, airport - engineer, airport technical, technical security, transport, versatile material security and support services.

The tactical level of logistics of the Ground Force Command of Slovak Armed Forces is shown in Figure 6.

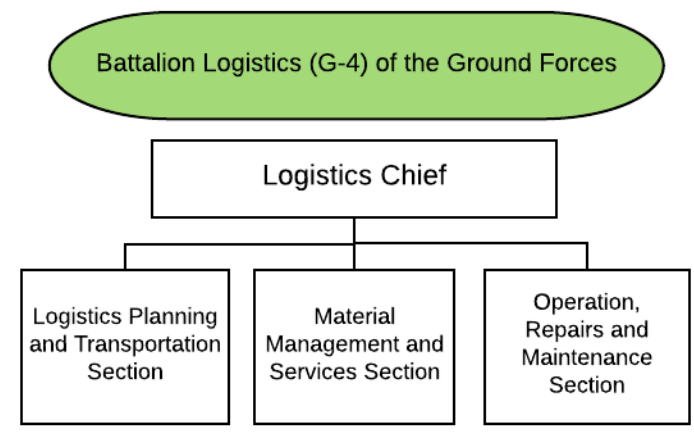

Fig. 6 Tactical Level of Logistics of Ground Force Command of the Slovak Armed Forces (Model)

The organizational structures of logistics are currently undergoing further reorganization and transformation (Sahin, 2017). The final conclusions on the structures are in the course of the discussions and remarks of the MOST top logistics authorities. There are no definitive decisions or resource aspects of building logistics structures. For these reasons, organizational logistics structures, logistics management, hierarchy, competencies, and dislocations will be addressed in the next logistics transformation period.

\section{CONCLUSION}

The long-term trend towards the future is the development of integrated logistics with the increasing demands for support of the management of NATO's expedition operations. To ensure a full range of operations, logistics should be versatile, agile, accessible, mobile, quickly deployable, and tailored to the task with minimal presence of forces and resources. Logistics for future operations must be highly prepared to withstand operations within 30 days (after the development of the supply system, of course, longer), capable of ensuring the arrival and deployment of units, and capable of acting independently or acting within a multinational joint task force (CJTF - Combined Joint Task Force).

The main priorities of the construction of logistics are the realization of all measures aimed at the timely and comprehensive security of troops, which include in particular: providing information 
processes in logistics, maintenance, operation and repair, supply, transport security, securing and provision of services.

Logistics in the Slovak Armed Forces has its organs at different levels of command. The Military Doctrine of the Slovak Armed Forces establishes three levels - strategic, operational and tactical, which apply to military and non-military operations (Brezula, 2017). The Ministry of Defence and the General Staff of the Slovak Armed Forces focus on the issue of strategic logistics. The
Headquarters of Training and Support addresses operational and some strategic logistics issues. After its abolition, its competencies will be transferred to the newly established Logistics Office directly subordinated to the GES of Slovak Armed Forces and to the components of ground and air force logistics. Territorial and Air Force logistics departments deal with operational logistics issues affecting the role of commanders in the operational plan for the use of the Slovak Armed Forces, including the creation of procedures, doctrines and training documents.

\section{WORKS CITED}

Brezula, J. (2017). Koncepcia kybernetickej bezpecnosti na Slovensku a pripravovane legislativne zmeny $v$ tejto oblasti: Zbornik vedeckych a odbornych prac Narodna a medzinarodna bezpecnost' 2017, (pp. 26-31). Liptovsky Mikulas.

Brezula, J. (2017). Prvky obrannej infrastruktury a ich vedenie $v$ ustrednej evidencii: Zbornik vedeckych a odbornych prac Narodna a medzinarodna bezpecnost' 2017, (pp. 32-37). Liptovsky Mikulas.

Marchevka, M. (2015). Vytvaranie zasob pre krizove situacie: Zbornik vedeckych a odbornych prac Narodna a medzinarodna bezpecnost' 2015, (pp. 381-388). Liptovsky Jan.

Trebula, M. (2016). Metódy optimalizacie materialoveho manazmentu aplikovatel'ne $v$ podmienkach vzdusnych sil Ozbrojenych sil Slovenskej republiky: Zbornik vedeckych a odbornych prac Narodna a medzinarodna bezpecnost' 2016, (pp. 533-543). Liptovsky Mikulas.

Sahin, S. (2017). Public international law and the self- proclaimed new lydeclaredre publics: Zbornik vedeckych a odbornych prac Narodna a medzinarodna bezpecnost' 2017, (pp. 396-501). Liptovsky Mikulas.

Skolnik, M., Belan, L. (2015). Obranne planovanie. Zaklady planovania a projektovania $v$ systeme obrany a bezpecnosti SR. Liptovsky Mikulas. ISBN 978-80-8040-522-9.

Received for publication:

Revision received:

Accepted for publication:
16.12.2017

28.12.2017

10.01 .2018

\section{How to cite this article?}

Style - APA Sixth Edition:

Skolnik, M. (2018, Jan 15). Logistics management in the armed forces of the Slovak Republic. (Z. Cekerevac, Ed.) MEST Journal, 6(1), 90-96. doi:10.12709/mest.06.06.01.10

Style - Chicago Sixteenth Edition:

Skolnik, Miroslav. 2018. "Logistics management in the armed forces of the Slovak Republic." Edited by Zoran Cekerevac. MEST Journal (MESTE) 6 (1): 90-96. doi:10.12709/mest.06.06.01.10.

Style - GOST Name Sort:

Skolnik Miroslav Logistics management in the armed forces of the Slovak Republic [Journal] // MEST Journal / ed. Cekerevac Zoran. - Toronto : MESTE, Jan 15, 2018. - 1 : Vol. 6. - pp. 90-96.

Style - Harvard Anglia:

Skolnik, M., 2018. Logistics management in the armed forces of the Slovak Republic. MEST Journal, 15 Jan, 6(1), pp. 90-96.

Style - ISO 690 Numerical Reference:

Logistics management in the armed forces of the Slovak Republic. Skolnik, Miroslav. [ed.] Zoran Cekerevac. 1, Toronto : MESTE, Jan 15, 2018, MEST Journal, Vol. 6, pp. 90-96. 